\title{
EFFECT OF SULPHUR FOLIAR APPLICATION ON YIELD AND GRAIN QUALITY OF SELECTED MALTING BARLEY VARIETIES
}

\author{
Hana Syrová ${ }^{1}$, Pavel Ryant ${ }^{1}$ \\ ${ }^{1}$ Department of Agrochemistry, Soil Science, Microbiology and Plant Nutrition, Faculty of AgriSciences, Mendel \\ University in Brno, Zemědělská 1, 61300 Brno, Czech Republic
}

Link to this article: https://doi.org/10.11118/actaun202068020351

Received: 2. 11. 2019, Accepted: 24. 2. 2020

To cite this article: SYROVÁ HANA, RYANT PAVEL. 2020. Effect of Sulphur Foliar Application on Yield and Grain Quality of Selected Malting Barley Varieties. Acta Universitatis Agriculturae et Silviculturae Mendelianae Brunensis, 68(2): 351-359.

\begin{abstract}
The aim of the experiment was to assess the influence of foliar application of sulphur on grain yield, N-substances and sulphur content in the grain. The content of dimethylsulphide (DMS) and its precursors (PDMS) of malt were determined. The study was performed in the form of a smallplot field trial between the years of 2010 and 2012, at a field trial station in Žabčice (South Moravia). Three malting barley varieties for the production of Czech beer (Aksamit, Bojos and Radegast) and three malting barley varieties for the production of export beer (Prestige, Jersey and Sebastian) were tested in that period. Sulphur (8 kg S per ha) was applied on leaves in the form of a suspension of micronized elementary sulphur with bentonite in stem elongation - first node (BBCH 31) and before end of heading (BBCH 57) of growth stages. Sulphur fertilization in both vegetation phases increased significantly grain yield and the most significant increase was detected after the application in $\mathrm{BBCH}$ 57. On the other hand, there was no accumulation of sulphur in the grain nor an increase in N-substances content. Sulphur fertilization did not increase DMS and PDMS content of malt as well.
\end{abstract}

Keywords: Barley, sulphur, N-substances, PDMS, DMS

\section{INTRODUCTION}

Sulphur is an important essential element with vital roles in plant metabolism such as the synthesis of sulphur organic compounds, amino acids and proteins. Proper nutrition with sulphur positively affects not only the yield, but also the quality of the total production of malting barley grain (Zhao et al., 2006). Until recently, atmospheric deposition (Zelený and Zelená, 1999) in addition to the application of fertilizers has provided enough sulphur supply. Due to environmental measures, the sulphur content of the air has dropped significantly and has to be delivered to plants otherwise. By 2010, the atmospheric sulphur deposition had decreased to $6.6 \mathrm{~kg} / \mathrm{ha}$ (CHMI, 2012). To produce one ton of the grain, barley takes up to $4.2 \mathrm{~kg}$ of sulphur (Richter et al., 2006). Malting barley is often grown on light soils that are more susceptible to sulphur deficiency than medium and heavy soils. A highly discussed topic is sulphur fertilization at a later stage of plant development. According to Zhao et al. (2006) the sulphur content in the grain may be increased, which could be reflected in the grain quality of the malting barley. Conversely, Fox et al. (2003) and Peltonen et al. (1994) have not confirmed this assumption. Grain quality of malting barley is given by the complex of properties such as carbohydrate and protein content, endosperm structure, activity of hydrolytic enzymes during malting and cell wall composition. When the sulphur nutrition is insufficient, the grain size may be lower thus reducing the germination energy of the grain (McGrath et al., 2002). Another important 
fact is that the application of sulphur can reduce the $\mathrm{N}$-substances content in the grain. This is due to the dilution effect caused by the increased grain yield. Under certain conditions and in specific locations, where the content of $\mathrm{N}$-substances in grain is higher, sulphur application can have this positive effect. Currently, there are more and more localities with the opposite situation. As an example, we can discuss the study provided by Radoch et al. (2010), who observed the decreasing content of $\mathrm{N}$-substances in the grain and hence lesser malting potential. It is clear, that the grains with content of N-substances below up to $10.5 \%$ are not maltable (Basařová et al., 2010).

The aim of this work was to assess the influence of foliar application of sulphur on yield, nitrogen and sulphur content in the grain and content of PDMS (dimethyl sulphide precursors) and DMS (dimethyl sulphide) in malt.

\section{MATERIALS AND METHODS}

The sulphur nutrition in malting barley selected varieties was performed in the form of a small-plot field experiment in the Obora field experimental station in the University Agriculture Enterprise Žabčice (N 49¹'59", E 16 37'59") between the years of 2010 and 2012. The experimental area is located at an altitude of $184 \mathrm{~m}$. The soil type is fluvial gley (FLG). The soil is medium to heavy, clay to clay-loam.

The soil exchange reaction and the content of available nutrients in individual years are given in Tab. I.
The soil exchange reaction $\left(\mathrm{pH} / \mathrm{CaCl}_{2}\right)$ was determined in an extract of $0.01 \mathrm{~mol} / \mathrm{C} \mathrm{CaCl}_{2}$ solution in ratio of 1:5 (Zbíral et al., 2002). The content of available $\mathrm{P}, \mathrm{K}, \mathrm{Ca}$ and $\mathrm{Mg}$ is determined in the Mehlich III extract (Zbíral et al., 2002). Soil leachate for the determination of accessible sulphur was prepared by the extraction with water in proportion of 1:5 (Zbíral et al., 2002). The mineral nitrogen content is determined in soil extract with potassium sulphate solution (1\%, $w / w)$ according to Zbíral et al. (2002).

The experimental station Žabčice can be described as one of the warmest regions of the Czech Republic in terms of long-term observation within the years from 1981 to 2010. It is characterized as a warm, slightly dry area with mild winters. The average annual air temperature is up to $9.2^{\circ} \mathrm{C}$. During the growing season, the average temperature is up to $15.7^{\circ} \mathrm{C}$. The average annual precipitation rate is $480 \mathrm{~mm}$. The figures from 1 to 4 show summary of monthly precipitation and the average monthly temperatures in years from 2010 to 2012 in comparison with the long-term average observation (1981-2010).

The six different varieties of malting barley were examined per each experimental year. These varieties are used for the production of Czech beer such as Aksamit, Bojos and Radegast and for the production of export beer such as Jersey, Prestige and Sebastian. Barley sowing was carried out in the last ten days of March. The uniform application of nitrogen of $40 \mathrm{~kg} / \mathrm{ha}$ in calcium ammonium nitrate was carried out the week after the sowing.

I: Results of soil analysis before the start of the experiment (Žabčice, October of 2010)

\begin{tabular}{cccccccc}
\hline \multirow{2}{*}{ Year } & $\mathrm{pH}\left(\mathrm{CaCl}_{2}\right)$ & \multicolumn{6}{c}{ Content of available nutrients $(\mathrm{mg} / \mathrm{kg})$} \\
\cline { 3 - 8 } & & $\mathrm{P}$ & $\mathrm{K}$ & $\mathrm{Ca}$ & $\mathrm{Mg}$ & $\mathrm{N}$ inorganic & S water-soluble \\
\hline 2010 & 7.0 & 115 & 216 & 4548 & 415 & 10.3 & 11.0 \\
2011 & 6.9 & 111 & 227 & 4694 & 530 & 17.4 & 5.8 \\
2012 & 7.1 & 113 & 211 & 4396 & 394 & 7.9 & 3.6 \\
\hline
\end{tabular}

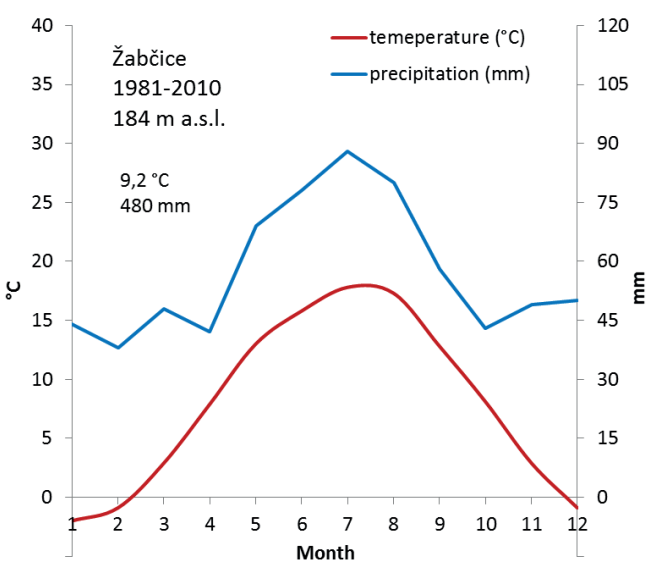

1: Average monthly temperature and sum of monthly precipitation in long-term observation (1981-2010)

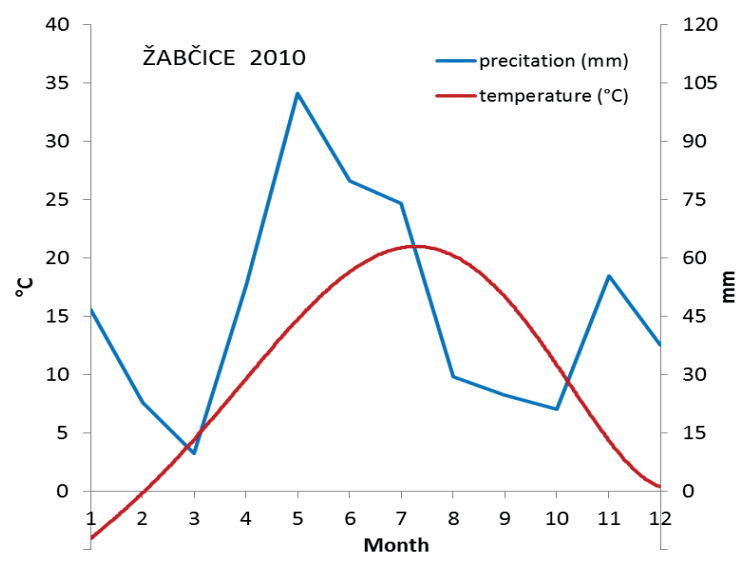

2: Average monthly temperature and sum of monthly precipitation in 2010 


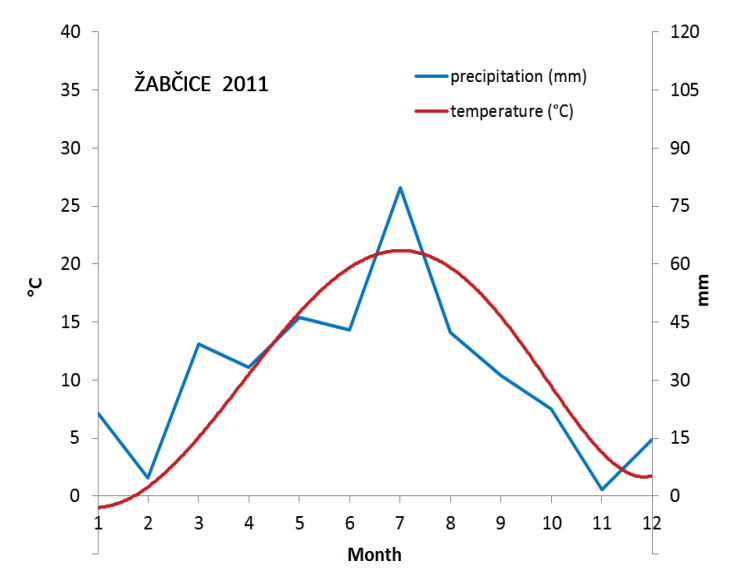

3: Average monthly temperature and sum of monthly precipitation in 2011

Plants were protected by standard herbicidal and fungicidal treatments. The harvest was carried out in the second half of July. In all experiments, spring wheat was a pre-crop. The experiment was always established in three repetitions with the non-residual small-scale Wintersteiger seed drill with a 4 million germinating seeds of seed rate. The following fertilization variations were included in the experiment: 1 . not fertilized with sulphur, 2. sulphur applied in $\mathrm{BBCH} 31$, 3. sulphur applied in $\mathrm{BBCH}$ 57. Sulphur was applied on leaves in the form of a suspension of micronized elemental sulphur with bentonite in DOLOSUL 80 WG $(80 \%$ of sulphur, manufacturer DÜKA, Germany) in dose of $8 \mathrm{~kg} S$ per ha. After the harvest, grain yield was determined in t/ha and converted to $14 \%$ of dry matter. Prior to the analysis, the grain was sorted, whereas the grains larger than $2.5 \mathrm{~mm}$ were used only. The nitrogen content in the grain was determined by the Kjeldahl method on the KJELTEC AUTO 1030 Analyzer (Zbíral et al., 2005). The sulphur content in the grain was determined by inductively coupled plasma optical emission spectrometry (ICP-OES) on a JY-24 instrument (Zbíral et al., 2005). The PDMS and DMS content in the malt were determined by gas chromatography according to Mikulíková (2010).

The effects of individual factors (the influence of the year, way of fertilizing and/or varieties) were statistically evaluated by multi-factor variance analysis followed by Tuckey test of significance of differences using STATISTICA software 12.0.

\section{RESULTS AND DISCUSSION}

\section{Grain Yield of Barley}

The weather was significantly reflected in the grain yield. In 2010 and 2011, the average yield of spring barley grain reached up to 6.3 t/ha. In 2012 the grain yield was $1.4 \mathrm{t} / \mathrm{ha}$, which was caused by a lack of precipitation in spring months (Fig. 4).

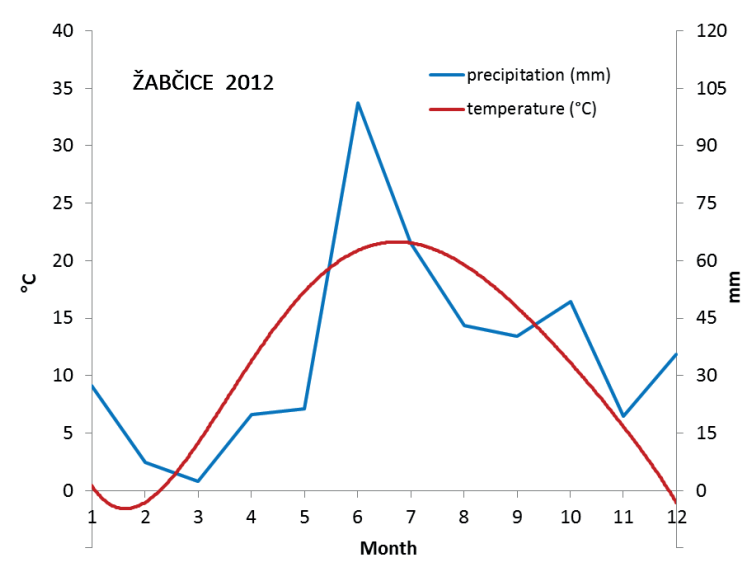

4: Average monthly temperature and sum of monthly precipitation in 2012

The foliar application of sulphur significantly increased the grain yield and the most significant increase was detected after the application in BBCH 57 (Fig. 5). Although, atmospheric sulphur deposition has until recently been considered as a sufficient source of sulphur for plants, Conry (1997) reported an increase in barley grain yield after foliar sulphur application in the southeast of Ireland in the early 1990s. Currently, Kozera et al. (2017b), Grzebisz et al. (2007), Dostálová et al. (2015) and De Bona et al. (2011) have also confirmed an increase in grain yield after the fertilization with sulphur.

All monitored varieties, some of them used to produce Czech beer (Aksamit, Bojos and Radegast), as well as varieties for the production of export beer (Jersey, Prestige, Sebastian), have reached an average yield of 4.2-5.0 t/ha for the three years monitoring period. As shown in Fig. 6, Prestige, Bojos and Aksamit responsed to the individual application dates most in terms of their yield.

\section{N-substances Content in Grain Barley}

The years of 2010 and 2011 were considered as relatively balanced in terms of the content of $\mathrm{N}$-substances in the grain, when we determined 8.7\% in 2010 and 8.9\% in 2011. N-substances were low due to the higher yield and the dilution effect. In terms of the requirements for N-substances content in grain in the Czech Republic (10.5\%-11.5\%), these grains have not been able to comply with the given range and cannot be used as quality malt. In 2012, on the other hand, the average content of $\mathrm{N}$-substances reached up to $15.9 \%$ due to very low yield (1.4t/ha). Therefore, barley grain obtained from this experimental year did not also match the qualitative parameters for malting. Nitrogen fertilization could be an issue for malting barley. Jankovic et al. (2011), Edney et al. (2012) and Yousif and Evans (2018) reported that nitrogen fertilization can increase the content of $\mathrm{N}$-substances in the grain and thereby may deteriorate the malting quality. They agree that the optimum dose of nitrogen is up 


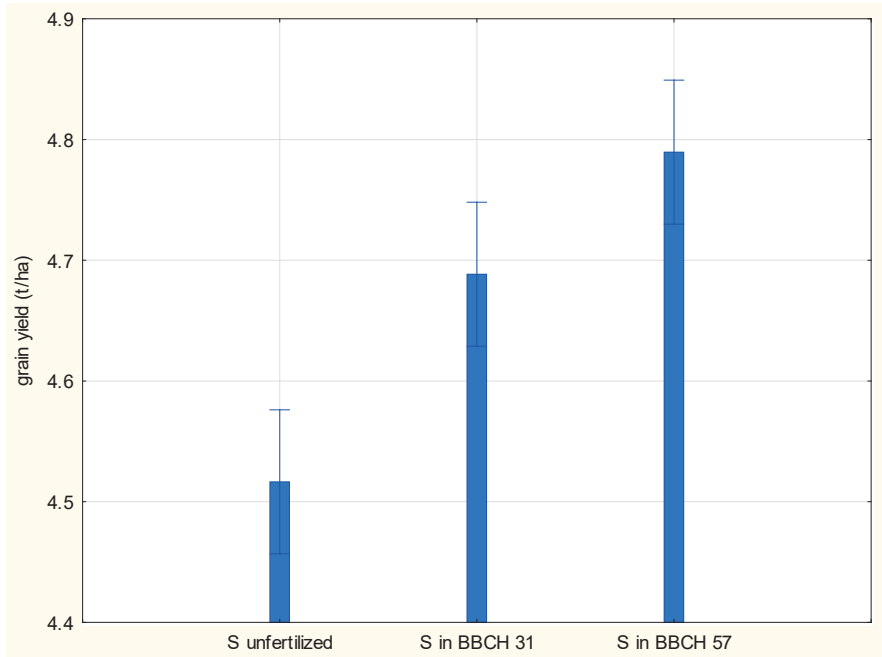

5: Effect of sulphur foliar application on barley grain yield (Žabčice, 2010-2012)

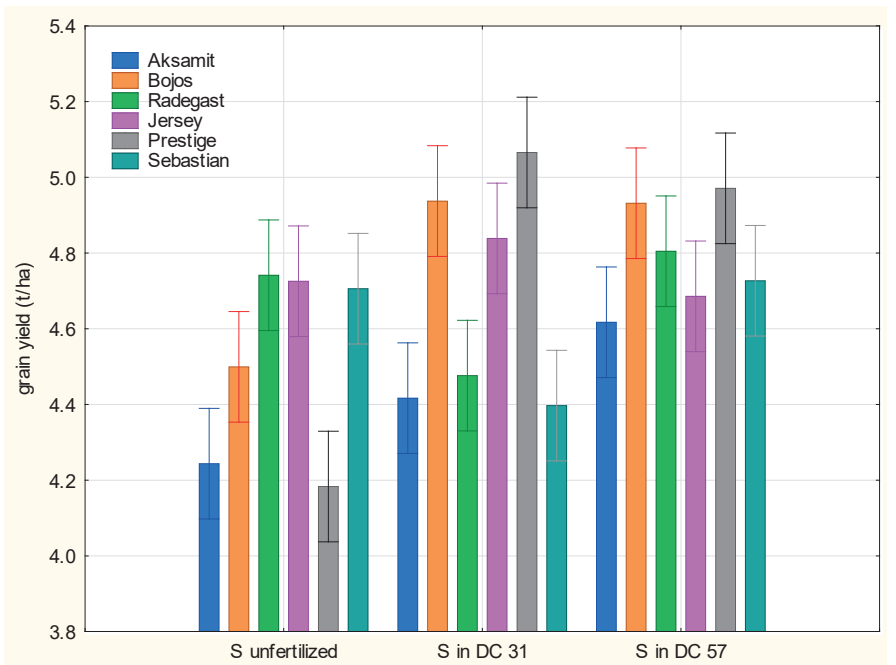

6: Effect of sulphur foliar application and variety on barley grain yield (Žabčice, 2010-2012)

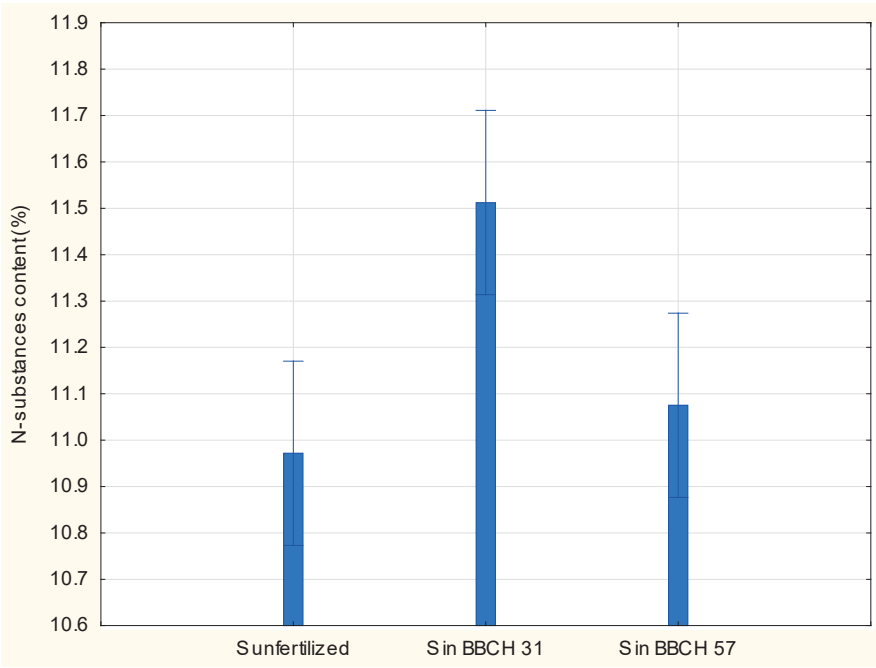

7: Effect of sulphur foliar application on the content of $N$-substances in barley grain (Žabčice, 2010-2012) 
to $50 \mathrm{~kg} / \mathrm{ha}$ for optimal yield and malting quality. In the experiment, nitrogen was applied in a total value of $40 \mathrm{~kg} / \mathrm{h}$, which could be one of the possible reasons for the decreased content of N-substances in grain in 2010 and 2011.

The foliar application of sulphur at the beginning of the stem elongation (BBCH 31) increased the content of $\mathrm{N}$-substances in the grain, compared to the control (Fig. 7). On the other hand, after the application of sulphur in BBCH 57, the content of N-substances was decreased. Similar conclusions are given by Grzebisz and Przygocka-Cyna (2007) and Zhao et al. (2006). Radoch et al. (2010) also described the reduction of $\mathrm{N}$-substances content after the application of sulphur fertilizers. Kozera et al. (2017a) reported a higher grain yield after sulphur application and a better metabolizing of nitrogen by plants. The possibility of reducing the content of N-substances after the application of sulphur in BBCH 57 can prove a positive effect in case of precipitation deficit and drying of plants. Thus, grains can show the optimum value of $\mathrm{N}$-substances despite of lower yields.

Fig. 8 shows the differences between the individual varieties in the content of N-substances in the grain after the application of sulphur in the individual experimental years and among the varieties. The average content of N-substances obtained from the examined varieties during the experiment ranged from 10.5 to $11.7 \%$. Two of varieties for the production of Czech beer (Aksamit, Bojos) displayed a higher content of $\mathrm{N}$-substances in the grain in comparison to varieties for the production of export beer (Jersey, Prestige, Sebastian). In this case, higher content of $\mathrm{N}$-substances in the grain was an issue (Basařová et al., 2010).

\section{Sulphur Content in Grain Barley}

The sulphur content in the grain is not directly responsible for the off-flavours and scents of beer, but under certain conditions, sensory active substances may be formed and can spoil the final product. For this reason, the sulphur content in the grain is a more-discussed topic in association with the malting quality. In the experimental years 2010 and 2011, the average sulphur content in the grain was up to $0.10 \%$. In 2012, the sulphur content in the grain reached up to $0.17 \%$. The sulphur content of barley grain depends on the variety, climatic conditions and the chosen cultivation technology. In malt, the total sulphur content depends on the chosen malting technology.

The sulphur content in the grain was not increased after the sulphur application in $\mathrm{BBCH} 31$ and in $\mathrm{BBCH} 57$ (Fig. 9) during our three years observations. In accordance with a higher grain yield after the sulphur application in $\mathrm{BBCH} 57$, the sulphur content in the grain obtained in the same variant was the lowest. Similar conclusions are given by Eriksen et al. (2002). They confirmed a decrease in the sulphur content in the grain after the application in the range of phenological phases from $\mathrm{BBCH} 39$ to $\mathrm{BBCH}$ 49. This result also indicates that even later application of sulphur can help to achieve the optimal malting quality of the grain. Conversely, Holopainen et al. (2015) and Zhao et al. (2006) reported an increase in the sulphur content in the grain after the application, which can reduce malt quality.

In this experiment, higher content of sulphur in grain was observed at the varieties Radegast and Bojos. Both varieties are included into the group of varieties for the production of Czech beer, so higher content of sulphur is desirable for a quality of the final product (Fig. 10).

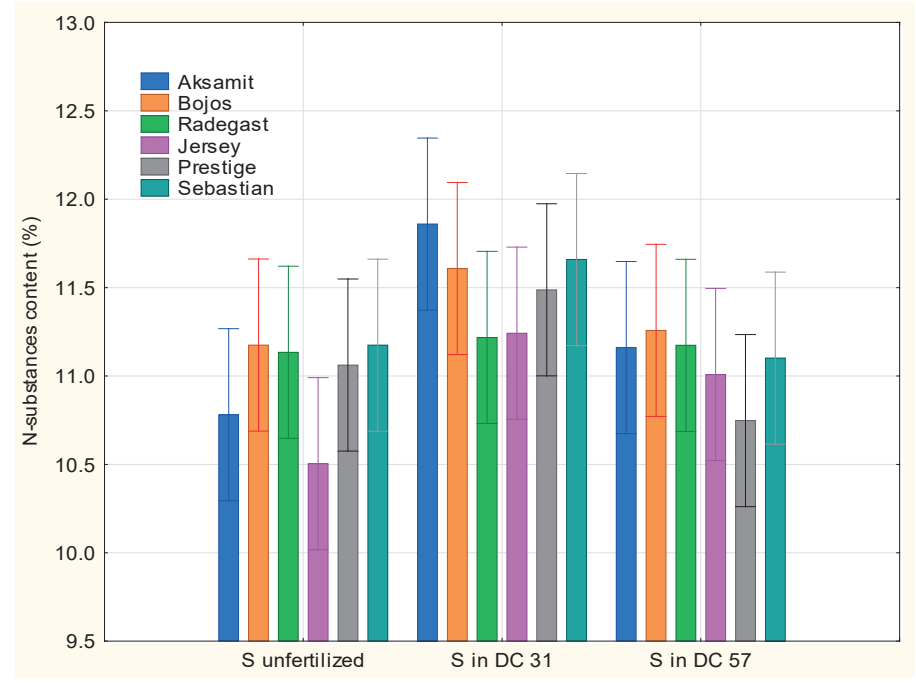

8: Effect of sulphur foliar application and variety on $\mathrm{N}$-substances content in barley grain (Žabčice, 2010-2012) 


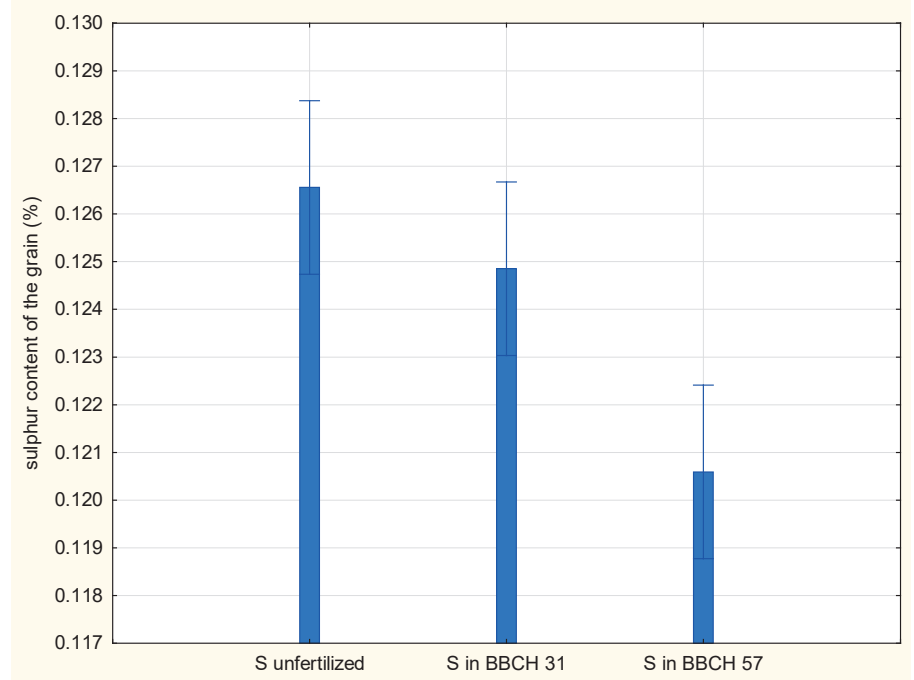

9: Effect of sulphur foliar application on sulphur content in barley grain (Žabčice, 2010-2012)

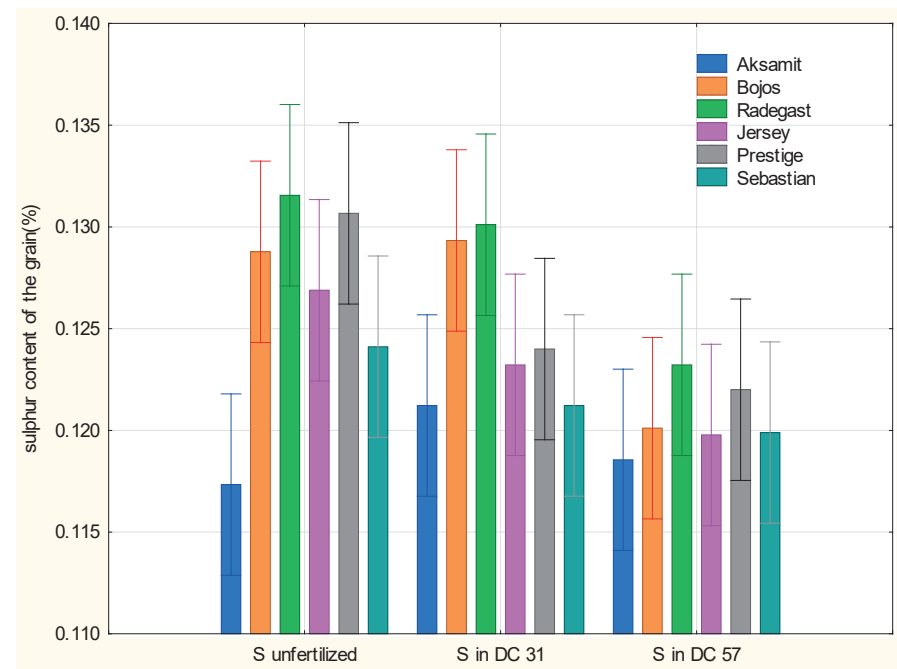

10: Effect of sulphur foliar application and variety on sulphur content in barley grain (Z̈abčice, 2010-2012)

\section{Content of Dimethylsulphide and Dimethylsulphide Precursors in Malt}

The content of DMS and PDMS is most often monitored in the final product, i.e. in beer. Their content is affected by the manufacturing technology. Kosař and Procházka (2000) reported of $50 \mu \mathrm{g} / \mathrm{l}$ as limited factor in beer. Mikulíková (2010) reported a range of values from 35 to $40 \mu \mathrm{g} / \mathrm{l}$ and Stafisso et al. (2011) described $100 \mu \mathrm{g} / \mathrm{l}$ as limiting concentration. According to Basařová et al. (2010), the maximum PDMS value for malt is up to $6 \mathrm{mg} / \mathrm{kg}$. Špinar et al. (1986) reported a range of malt types of $2-15 \mathrm{mg} / \mathrm{kg}$ for light malt and from 1 to $3 \mathrm{mg} / \mathrm{kg}$ for dark malt. Sulphur application during the vegetation did not cause an increase in PDMS and
DMS content of malt. The lowest content of PDMS and DMS was found after the application of sulphur in BBCH 57 (Fig. 11 and Fig. 13). The PDMS content of the malt samples of different varieties ranged from 2.58 to $6.24 \mathrm{mg} / \mathrm{kg}$. In the case of DMS, we determined 2.70 to $7.36 \mathrm{mg} / \mathrm{kg}$.

Significantly higher values of PDMS and DMS were achieved in three varieties of malting barley cultivated for the production of Czech beer Aksamit, Bojos and Radegast, by which is mostly desired the varietal character (Fig. 12 and Fig. 14). Zhao et al. (2006) reported that the PDMS content, namely S-methylmethionine, was significantly increased after the increase of sulphur content in the grain. However, the data obtained from this experiment did not confirm this fact. 


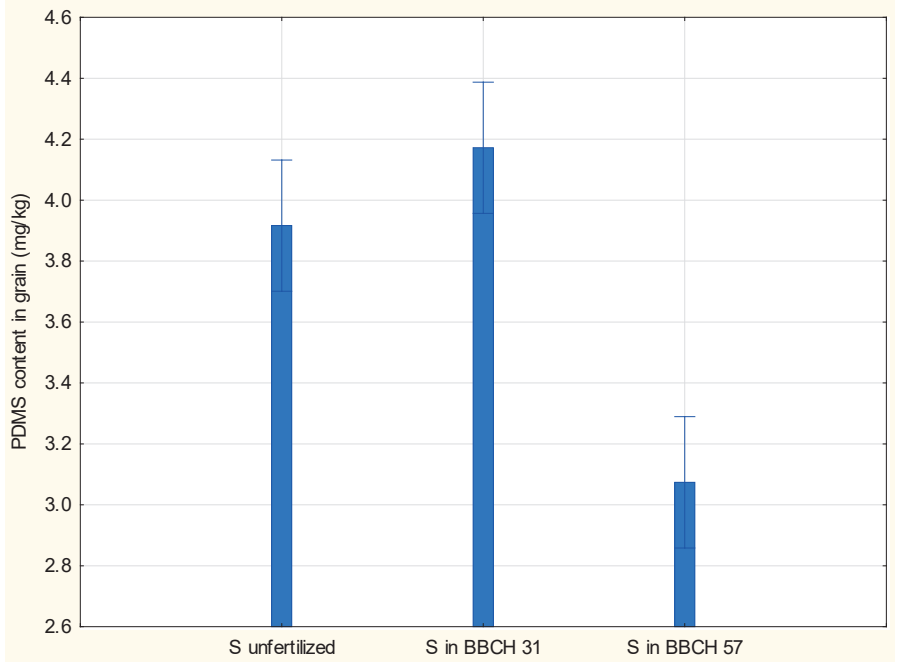

11: Effect of sulphur foliar application on PDMS content in malt (Žabčice, 2010-2012)

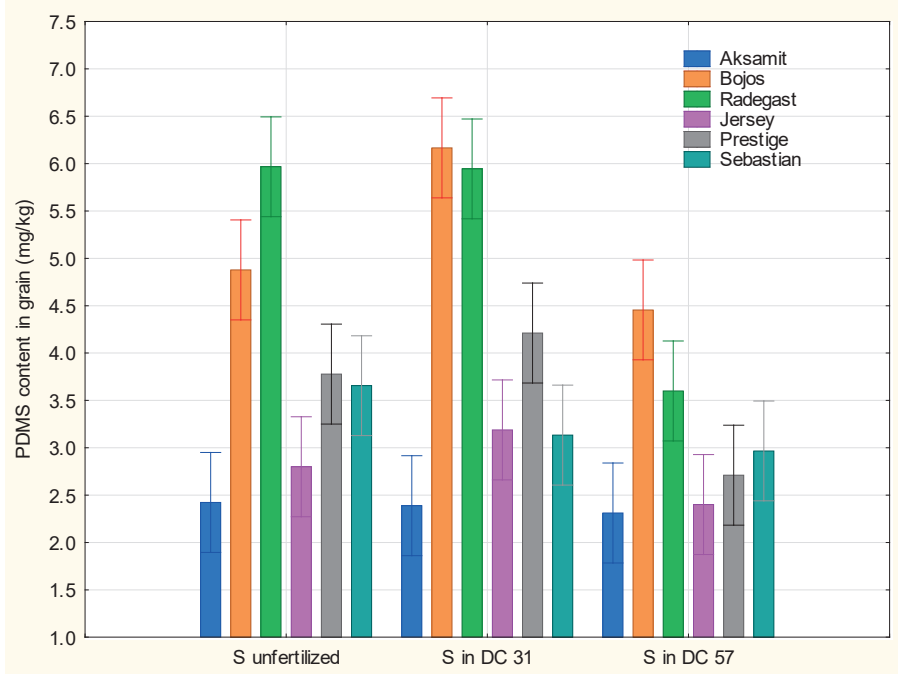

12: Effect of sulphur foliar application and variety on PDMS content in malt (Žabčice, 2010-2012)

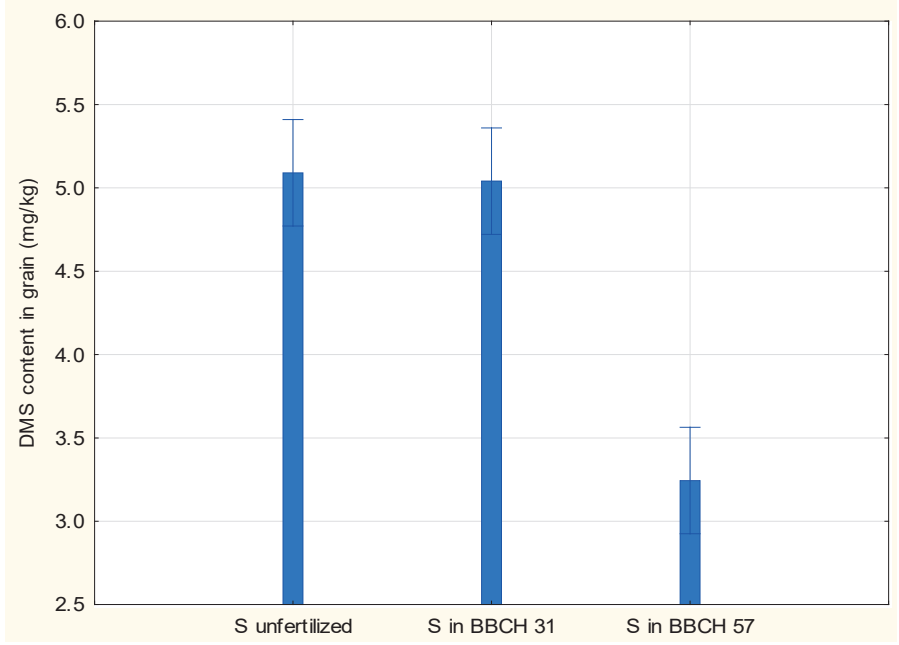

13: Effect of sulphur foliar application on DMS content in malt (Žabčice, 2010-2012) 


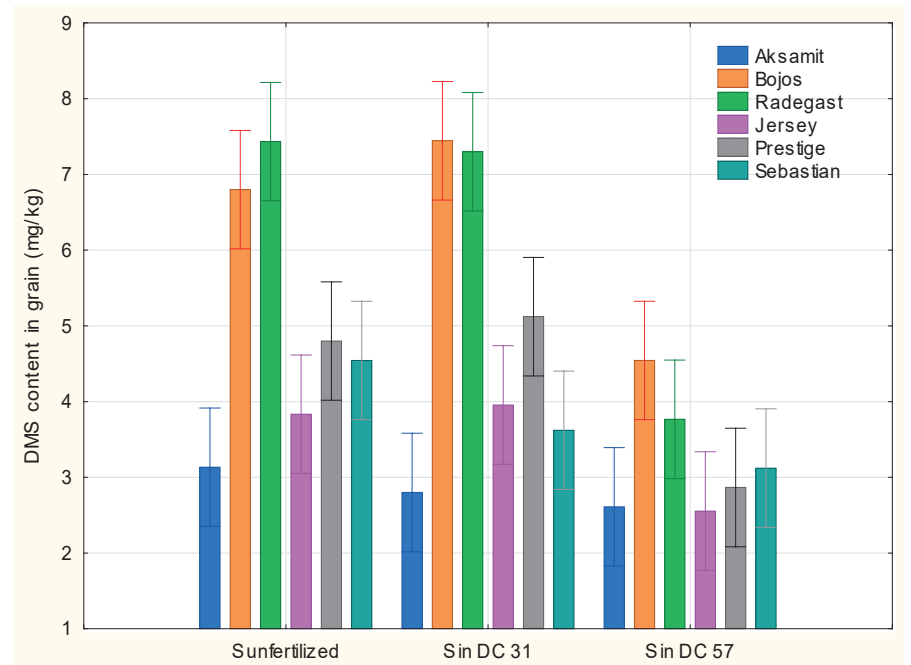

14: Effect of sulphur foliar application and variety on DMS content in malt (Žabčice, 2010-2012)

\section{CONCLUSION}

The grain yield of malting barley was significantly influenced by the different course of weather during experimental years. Despite the differences between the years, the increase in grain yield has been proved to be significant after the foliar application of sulphur in $\mathrm{BBCH} 31$ or in BBCH 57. Prestige, Bojos, Aksamit varieties reacted most strongly to the different terms of sulphur application. The N-substances content did not meet the specified requirements in any of the years, therefore, the grains were not suitable for malting. The average content of N-substances from the experiment dropped conclusively after the application of sulphur in $\mathrm{BBCH}$ 57. The difference between the varieties was statistically inconclusive, however, the Aksamit and Jersey varieties provided highest content of N-substance.

Sulphur content in the grain was not increased after the application of sulphur in $\mathrm{BBCH} 31$ or BBCH 57 in any experimental years. The lowest sulphur content was consistent with the highest yield in grain after sulphur fertilization in $\mathrm{BBCH}$ 57. The differences between the varieties were not statistically conclusive, while the highest average sulphur content was observed at Prestige variety. With the decrease in sulphur content, a decrease of PDMS and DMS was observed in the malt. The content of DMS and its precursor was the lowest after the application of sulphur in BBCH 57. Three varieties of malting barley cultivated for the production of Czech beer - Bojos, Prestige and Radegast - showed significantly higher content of PDMS and DMS, which is usually the desired feature.

\section{Acknowledgements}

The authors acknowledge the financial support of the Ministry of Education, Youth and Sports of the Czech Republic (Project RC No. 1M0570).

\section{REFERENCES}

BASAŘOVÁ, G., ŠAVEL, J., BASAŘ, P. and LEJSEK, T. 2010. Brewing, theory and practice of beer production [in Czech: Pivovarství, teorie a praxe výroby piva]. Praha: VŠCHT Praha.

CONRY, M. J. 1997. The influence of different nitrogenous fertilisers and foliar-applied sulphur on the yield, grain nitrogen and screenings of spring malting barley. Biology and Environment-proceedings of the Royal Irish Academy B, 97(2): 133-138.

CHMI. 2012. Air Pollution in the Czech Republic. Czech Hydrometeorological Institute. [Online]. Avaialable at: http:/portal.chmi.cz/files/portal/docs/uoco/isko/grafroc/groc/gr12cz/kap3.html [Accessed: 2020, February 15].

DE BONA, F. D., FEDOSEYENKO, D., VON WIREN, N. and MONTEIRO, F. A. 2011. Nitrogen utilization by sulfur-deficient barley plants depends on the nitrogen form. Environmental and Experimental Botany, 74: 237-244. 
DOSTÁlOVÁ, Y., HŘivNA, L., KOTKOVÁ, B., BUREŠOVÁ, I., JANEČKOVÁ, M. and ŠOTTNÍKOVÁ, V. 2015. Effects of nitrogen and sulphur fertilization on the quality of barley protein. Plant, Soil and Environment, 61(9): 399-404.

EDNEY, M. J., O DONOVAN, J. T., TURKINGTON, T. K., CLAYTON, G. W., MCKENZIE, R., JUSKIW, P., LAFOND, G. P., BRANDT, S., GRANT, C. A. and HARKER, K. N. 2012. Effect of seeding rate, nitrogen rata and cultivar on barley malt quality. Journal of Cereal Science, 92(13): 2672-2678.

FOX, G. P., PANOZZO, J. F., LI, C. D., LANCE, R. C. M., INKERMANN, P. A. and HENRY, R. J. 2003. Molecular basis of barley quality. Australian Journal of Agricultural Research, 54: 1081-1101.

GRZEBISZ, W. and PRZYGOCKA-CYNA, K. 2007. Spring malt barley response to elemental sulphur the prognostic value of $\mathrm{N}$ and S concentrations in malt barley leaves. Plant, Soil and Environment, 53(9): 388-394.

HOLOPAINEN, U. R. M., RAJALA, A., JAUHIAINEN, L., WILHELMSON, A., HOME, S., KAUPPILA, R. and PELTONEN-SAINIO, P. 2015. Influence of sulphur application on hordein composition and matling quality of barley (Hordeum vulgare L.) in northern European growing conditions. Journal of Cereal Science, 62: 151-158.

JANKOVIC, S., GLAMOCLIJA, D., MALETIC, R., RAKIC, S., HRISTOV, N. and IKANOVIC, J. 2011. Effects of nitrogen fertilization on yield and grain quality in malting barley. African Journal of Biotechnology, 10(84): 19534-19541.

KOSAŘ, K. and PROCHÁZKA, S. 2000. Technologie výroby sladu a piva. Praha: VÚPS.

KOZERA, W., BARCZAK, B., KNAPOWSKI, T., BRUDNICKY, A. and WICHROWSKA, D. 2017a. Response of spring barley to NPK and S fertilisation: Yielding, the content of protein and the accumulation of mineral nutrients. Journal of Elementology, 22(2): 725-736.

KOZERA, W., BARCZAK, B., KNAPOWSKI, T., SPYCHAJ-FABISIAK, E. and MURAWSKA, B. $2017 \mathrm{~b}$. Reaction of spring barley to NPK and S fertilization. Yield, the content of macroelements and the value of ionic ratios. Romanian Agricultural Research, 34: 275-285.

MCGRATH, S. P., ZHAO, F. and BLAKE-KALFF, M. M. A. 2002. Sulphur in Soil: Processes, Behaviour and Measurement. In: Proceeding of the International Fertiliser Society, No. 499. IFS.

MIKULÍKOVÁ, R. 2010. Study of selected types of sulphur compounds in beer and brewing materials [in Czech: Studium vybraných typů sirných látek v pivu a pivovarských surovinách]. Dissertation Thesis. Brno: Vysoké učení technické v Brně.

PELTONEN, J., RITA, H., AIKASALO, R. and HOME, S. 1994. Hordein and malting quality in northern barleys. Hereditas, 120: 231-239.

RADOCH, T., HŘIVNA, L. and HOMOLA, L. 2010. Effect of sulphur on quality malting barley. [in Czech: Vliv aplikace síry na jakost sladovnického ječmene]. In: Sladovnický ječmen-přiměřená ekonomika, vysoký výnos a kvalita zrna, pp. 51-52.

RICHTER, R., HŘIVNA, L. and RYANT, P. 2006. Spring barley nutrition and fertilization. [in Czech: Výživa a hnojení ječmene jarního] In: ZIMOLKA, J. et al. (Eds.). Barley - forms and utility trends in the Czech Republic [in Czech: Ječmen - formy a užitkové směry v České republice]. Praha: Profi Press.

ŠPINAR, B., KELLNER, V. and ČULÍK, J. 1986. Dimethylsulphide in beer and malt [in Czech: Dimethylsulfid v pivě a sladu]. Kvasný průmysl, 32(5): 98-101.

STAFISSO, A., MARCONI, O., PERRETTI, G. and FANTOZZI, P. 2011. Determination of dimethyl sulphide in brewery samples by headspace gas chromatography mass spektrometry (HS - GC/ MS). Italian Journal of Food Science, 23(1): 19-27.

YOUSIF, A. M. and EVANS, D. E. 2018. The impact of barley nitrogen fertilization rate on barley brewing using a commercial enzyme (Ondea Pro). Journal of the Institute of Brewing, 124(2): 132-142.

ZBÍRAL, J. 2002. Soil Analysis I - Uniform Workflows [in Czech: Analýza půd I - Jednotné pracovní postupy]. Brno: ÚKZÚZ.

ZBÍRAL, J. et al. 2005. Analysis of Plant Material - Uniform Workflows [in Czech: Analýza rostlinného materiálu - Jednotné pracovní postupy]. Brno: ÚKZÚZ.

ZELENÝ, F. and ZELENÁ, E. 1999. Sulphur and its need for plant nutrition [in Czech: Síra a její potřeba pro výživu rostlin]. Praha: Ústav zemědělských a potravinářských informací.

ZHAO, F. J., FORTUNE, S., BARBOSA, V. L., MCGRATH, S. P., STOBART, R., BILSBORROW, P. E., BOOTH, E. J., BROWN, A. and ROBSON, P. 2006. Effects of sulphur on yield and malting quality of barley. Journal of Cereal Science, 43(3): 369-377. 